Afrika Focus, Vol. 17, Nr. 1, 2001, pp. 79-111

\title{
THE PLACE OF SUB-SAHARA AFRICA IN THE WORLDSPORTSYSTEM
}

\section{Trudo DEJONGHE}

\author{
Lessius Business School \\ Korte Nieuwstraat 33 \\ B - 2000 Antwerpen
}

e-mail: trudo.dejonghe@lessius-ho.be

\section{SUMMARY}

The place of Sub-Sahara Africa in the Worldsportsystem

The contemporary world sportsystem is developed through globalisation with its homogenisation and heterogenisation processes. The result of these opposite forces is the division of the world in 6 classes. Sub-Sahara Africa underwent, with the exception of SouthAfrica, Namibia and Zimbabwe, a total and passive acceptance of the western (British) modern sports. The place of that part of Africa is analogue to and correlates with its place in Wallerstein's worldsystem periphery. The introduction of modern sports is associated 
with the spatial diffusion of the 19th century British hegemonic cultural imperialism. The purpose of this policy was a transformation of the traditional society into a modern functional world-culture and the incorporation of that part of the world in the world-system.

The anti-western feelings after the independence resulted in a political Pan-Africanism. However, sport and more specific soccer, a typical product of the western domination, has not been rejected. On the contrary, local politicians used it to create a national identity. The strong link between soccer and soil resulted in a strong form of topophily. This connection was transformed into sportnationalism and created in the, through artificial borders developed, nations a unity and a national pride. The outcome of sport games was used to demonstrate the successes in politics and economics. The absence of any political platform on which the Third World had a strong voice brought about that the international sport scene, such as the FIFA, was used for the unification of the Third World against the former colonial powers. Nowadays, the globalisation processes result in an increasing labour migration of African football players to the rich core competitions in Europe. This form of migration can be classified as another form of "cash crop" or in this case "foot drain.."

"As Roman imperialism laid the foundation of modern civilisation and led wild barbarians of these islands (Britain) along the path of progress, so in Africa today we are repaying the debt, and bringing to the dark places of the earth - the abode of barbarism and cruelty - the torch of culture and progress... we hold these countries because it is the genius of our race to colonise, to trade and to govern"(quote by the English educationist Sir Frederick Lugard (1858-1954) in Mandell, 1986: p.102).

Key Words: foot drain, globalisation, labour migration, national identity, soccer, sport nationalism, world sport-system. 


\section{INTRODUCTION}

Globalisation is the social science of the 1990s and "popular culture" takes an important central place. Cultural globalisation, as a dimension of the total process, refers to the consumption of global products across the world and often implies a homogenising process described as Cocacola-isation or Mc Donaldisation, (Friedman, 1994: p.195; Waters, 1995: p.137; Renson, 1997: p.47; Crang, 1998: p.113; Taylor, 1999: p.123; Beck, 2000: p.42). Modern sports can be classified as a part of the popular (global) culture. People across the world are willing and expect to see the global events "World Cup Football" and "Olympic Games" on their TV-screen. Modern sport is thereby an example of cultural and geographical globalisation and according to Maquire, (1999: p.34) a part of the global homogeni-sation process.

The spatial diffusion of modern sports started in the 19th century. Europe exported its customs, universal ideas, science,... and its modern sports as an element of cultural diffusion, across the world. Mangan, (2001: p.2) states that the sports were variously received; they were assimilated, imitated likewise, occasionally resisted and adapted to local talents, preferences, needs and possibilities. Dunning (1999) classifies the export in the $19^{\text {th }}$ century of European and more specific the "Anglo-Saxon" modern sports as the take off phase of the sportisationprocess. Dejonghe, (2001b; p.29-30) links this process with the take off phase - with a rising consciousness of globalisation, nationalism and standard scientific methods - of the modernisation theory.

The question that can be asked in this context is "Where is the place of Sub-Sahara Africa in these processes? Is this part of the world a place of sportresistance or sportassimilation? What's his place in the worldsport-system? What is the function of Sub-Sahara Africa in the globalisation process? Is labour migration of sportathletes another example of "cash crop" of "brain drain"? 


\section{THE CREATION OF THE WORLD SPORT-SYSTEM}

The first laws ever to be voluntarily embraced by men from a variety of cultures and backgrounds are the laws of sport, (Mazrui, 1976: p.411).

\subsection{World-system analysis and the globalisation of sport}

Dejonghe, (2001a: p.22-24; 2001b: p.33-36) assumed that the spatial diffusion of modern sport was/is determined by a combination of the characteristics of 19th century nationalism and Wallerstein's worldsystems analysis. World-systems analysis assumes that social changes don't occur country by country but in a global scope. The societies and countries become a part of a larger whole. A social change in one country can only be understood within the context of the system. It is a reaction against the modernisation theories of the $60 \mathrm{~s}$ and $70 \mathrm{~s}$ and is an attempt to understand global inequality patterns. The holistic approach of world system analyses means that the social sciences as a whole need a geographical and historical dimension. Time and space have to be the core of research. The time-dimension is Braudel's "longue durée" ${ }^{1}$ and the geographical unit is the social system like the world system. This approach argues that a world system of economic, geographical, historical and political connections is the capitalist world-economy that has been in its place since the 16th century. In order to analyse the social system as a whole, we used Wallerstein's (1974) global framework of capitalist economy. This framework circulates around a three-tier structure, i.e. the core with the dominating hegemony, the semi-periphery and the periphery. The parts of the world not incorporated in the capitalistic world-economy were

\footnotetext{
'Fernand Braudel's concept of the gradual change through the day-to-day activities by which social systems are continually being reproduced, (TAYLOR \& FLINT, 2000: p.372).
} 
defined as the external zones. The crux of Wallerstein's framework is that the core countries dominate the world economy and preserve their position by constructing world trade practices to ensure their economic status. According to Taylor (1999: p.35) the hegemony, the dominating world leader, is linked with the conjunctural long-term cycles. The economical comparative advantages of the hegemony are associated with a cultural domination. In the 19th century and more specific in the period $1815^{2}-1873$ the UK was the hegemon. In the third quarter of the 19th century and the beginning of the 20th century the hegemon status became a topic of discussion. The US and continental Germany were competing for world hegemony with the UK. The struggle for hegemony was determined by the two world wars and the US became the leader of the "free world" until 1973.

\subsection{The globalisation of the world-sportsystem}

Until recently sport was traditionally viewed as a cultural product that exists in the realm of economy. The Dutch sociologist Van Bottenburg, (1994: p.137) observed that the percentage of the population participating in sport of British origin are dominating the world and that the American sports are most of the time in second or third place (central Europe). Dejonghe, (2001a: p.139-159) noticed that the global domination of British sports and in a less degree American en German sports is the result of the cultural diffusion or by some authors called cultural imperialism of the universality of hegemony. In Africa is football ${ }^{3}$ an extend of cultural diffusion a legacy of European colonialism. According to Darby, (2001: p.218) is the advent and development of European colonialism the most significant factor in the socio-cultural transformation of African society.

\footnotetext{
${ }^{2}$ The hegemony struggle between France and the UK was decisive by the Napoleon wars.

${ }^{3}$ In English (American) literature is football soccer. In this article is only "football" used.
} 
"As part of this change forms of European sports supplanted the traditional cultural of games, sports and dance and it was not long before football captured the imagination of indigenous populations resulting in rapid and mass popularisation... Although it is difficult to generalise about the spread of the game in an area that is as geographically vast and ethnically diverse as Africa, it is possible to identify a number of central features of the game's development throughout the continent", (Darby, 2001: p.218).

Globalisation is not developed on a neutral plain but is ented on Wallerstein's world-system. According to Marshall, (1996: p.886) it replaced the higher systemic integration not the core/periphery structures or core rivalry. The question becomes how does imperialism operates under conditions of globalisation?

Taylor \& Flint, (2000: p.143) illustrates the continuing imperialism manifest in globalisation by describing subjects in which imperial relations of dominance are clear to see. The cultural imperialism on new communication and the victory of the neo-liberal paradigm in the third world, has created a new dependency.

The outcome of the 19th century hegemonic processes of sportdiffusion and universalism results in combination with the recent globalisationprocesses in a further homogenisation of sport practice in the world. These global sportification processes were, according to Maquire, (1999: p.41) more symptomatic of the emergence of a transnational culture than any other aspect in social life. Globalisation should create the world as "one place" and with a "geo-culture" that could be transplanted on the national variants. Schiller defined the globalisation process as

"the sum of the processes by which a society is brought into the modern world-system and how its dominating stratum is attracted, pressured, forced and sometimes bribed into shaping social institutions to correspond to, or even promote, the values and structures of the dominating centre of the system", (Schiller, 1976: p.9). 
Western standards are in this context seen as a second nature and are used to symbolise the uniformity of the globalisation process. Sport and its derivative activities have taken an important place in the western world. It became a central element of the contemporary popular culture and the collective or personal identity formation in the modern world. Moreover it is one of these universalistic popular cultures, which evolved to the centre of our society and became an expression of civilisation and modernity. The key network of global communication - and the industries organised round them - is the entertainment business where sport plays a significant role. This form of cultural hegemony and spatial diffusion of the western sports is by some authors, (Mangan, 1986; Tomlinson, 1991; Gutmann, 1994; Bale, 1994; Houlihan, 1994; Maquire, 1994; 1999; Arundel \& Roche, 1998) classified, just like languages, literature and mass-media, as a component of cultural imperialism, a form of domination not just in political and economic spheres but also over those practices by which collectivities make sense of their lives. The modern sports substituted the local traditional games and sport-globalisation was an element of westernisation and just another reflection of the balance of power in cultural exchange. The core-periphery relation in combination resulted in a sport dependency and Africa is integrated in the worldsportsystem as a resource of labour or in our case "cheap" athletes or "footdrain".

\subsection{World sportsystem: classification}

The changing hegemony in the 19th and 20th century and the rise of the 20th century ethnic nationalism - which was a form of resistance against cultural hegemony - repulsed in some ways sport-homogenisation, (Wagner, 1990; Apparudai, 1990; Nederveen Pieterse, 1995). Globalisation is not a coherent and cultural directed process but the outcome of a complex dynamism of political, economical and cultural factors. The interdependence and interconnection in the global space has as result a cross-pollination and not a unilateral diffusion of core cultures. A paradoxical consequence of globalisation is not to produce homogeneity but to familiarise us with great diversity; the extensive range of local cultures and the process of globalisation lead to an increasing sensitivity to differences. The adoption and local 
adaptation of the introduced western culture resulted in a creolisation of the original forms and created an "infinitely varied mutual contest of sameness and difference", (Apparudai, 1990: p.308). Cultural diffusion can transform the local culture but the "invention of traditions" made it possible to conserve, create and recreate the local cultural heterogeneity. Giddens, (1990: p.59) noticed that the creation of a transnational culture was not necessary in the globalisation process because the implementation should result in a tension between cultural homogenisation and heterogenisation processes. The penetration of the western values is superficial and the uprising nationalistic, ethnical and fundamentalist reactions could, according to Gellner, (1994: p.49-50) result in the resurrection of reinvention of the local entropy resistant subculture ${ }^{4}$. The local elite was the leader of the cultural resistance and led a revival of their sometimes-invented traditional cultural heritage incorporated in modern 20th century cultural or ethnical nationalism.

These contradictionary processes of homogenisation and heterogenisation resulted in a spatial classification system for sports with two variables:

- total or partial reach

- passive, participating or conflictual response

- passive: the external culture is accepted or there is no possibility of resisting it

- participating: there is a negotiation between the global and local culture

- conflictual: resistance and a pattern or attempt of rejection.

${ }^{4}$ Entropy-resistance occurs when a society evolves from agrarian to industrial associated with a form of entropy. The agrarian society, with relatively stable specialisations and an obstinate regional social character, relationship or hierarchical system has a marked social structure. In the industrial society these are not a strict and the old structures are of no importance. Entropy-resistance occurs when those old structures are able to resist the new societal demands, (GELLNER, 1984: p.49-50). 
This results in the existence of 6 more or less homogeneous subdivisions of the world-sportsystem:

\begin{tabular}{|l|c|c|c|}
\hline & Passive & Participating & Conflictual \\
\hline Total & A & B & C \\
\hline Partial & D & E & F \\
\hline
\end{tabular}

Table 1: Patterns of sport globalisation

The Sub-Sahara African nations are, with the exception of South Africa and Namibia, divided in A., the areas with a total and passive acceptance of the imported sports. This part of the continent is located in the periphery of the sport world-system and underwent the western cultural diffusion. This part of the continent entered the world-system in the age of imperialism at the moment of British hegemony. SubSahara Africa is being used as a supplier of athletes for the core and semi-peripheral sportregions in the world. The athletes can be seen as a form of "cash crop". The region is submerged in, just like parts of Latin America and the Caribbean's, a form of "cultural imperialism" and the modern western sports were totally adopted in the local sportsystems. The difference between Latin America, the Caribbean and Sub-Sahara Africa is that in Latin America and the Caribbean parts were politically independent and incorporated in the economic structures of the British or Americans. These regions underwent a homogenisationprocess and the local games became less popular. In this category are also the South-European countries such as Italy, Spain, Greece, the Balkan states and Portugal been classifies. These countries used in the past the British, American and German modern sports as an expression of the supremacy of their political authoritarian system and their centralised nationalism.

The modern sports underwent in some cases a creolisation or hybridisation. The formal British colonies South Africa, Australia, Canada, New Zealand and in a less degree Zimbabwe and Namibia 
were colonies of white settlers. They accepted and/or transformed ${ }^{5}$ the modern sports, which were associated with the white elite and can be placed in class B. The result of the spatial diffusion of the British hegemonic power was a mass migration of white settlers to the overseas territories. They invented local variants of the more formalised British sports such as football, rugby and Gaelic football or accepted the sport like rugby, cricket and hockey that were associated with white supremacy.

The other subdivisions are less important in this article:

C: post revolutionary Russia/USSR, its satellite states in Eastern Europe and China. They accepted the "capitalistic" sports as expression of economic and cultural struggle against capitalism. Sport was an indicator of economic success and supremacy.

D and E: regions that adopted some western sport and kept their traditional local sports. In India, Sri Lanka and Pakistan are the local games combined with the "elitesports" like hockey and cricket, in the Middle-East with football and in SE Asia are the martial arts combined with American sports like baseball, the Olympic sports for prestige and recent with British football and hockey). The western, central and northern European countries combined the British with German, American sports, wintersports and some local sports.

F: the regional and local entropy-resistance against a hegemonic power. The example is the Gaelic Athletic Association(Gaelic Football and Hurling) in Ireland.

\footnotetext{
${ }^{5}$ Australia has its football hybrid "Australian Football". It is a mix and hybridisation of Rugby and Gaelic (Irish) Football. Canada has hid Canadian Football, a hybridisation of rugby.
} 
The two main questions, which can be put, are:

What process was dominant in the distribution of sport in Sub-Sahara Africa?

Why has sport, as an expression of western culture and modernisation theory not been rejected after the independence?

\section{THE DISTRIBUTION OF SPORT IN SUB-SAHARA AFRICA}

\subsection{The 19th century hegemonic sportstructures}

"The parallel patterns of these two processes, of the diffusion from England of industrial models of production, organisation and work, and the diffusion of spare-time occupations of the type known as "sport" and of the types of organisation connected with it is certainly striking", (Elias \& Dunning, 1986: p.150).

In the 16 th -17 th century, the European states only secured settlements on the African coast, from where they exported slaves received from local slave-trading states. This trade was only a luxury exchange with an external arena. The "expansion-scramble for Africa", the incorporation of the continent in the pheripherical zone of the worldsystem occurred in the classical age of imperialism and the continent stayed in that situation until today, (Taylor \& Flint, 2000: p.23; p.123). The notion hegemony and modernity do not have the same meaning but they are correlated with each other. Modern and worldsystem were related and resulted in a hegemonic culture, which was considered as "the modern civilisation" or "universality". Taylor, (1996: p.83) argued that the way of thinking was "that what good was

\footnotetext{
${ }^{6}$ Britain abolished slave trade in 1807 and the continent became a source of commodities for the world market.
} 
for the hegemony is good for the world". The British hegemony in the world-system in the 19th century is correlated with industrialisation. This new form of accumulation of capital created a concentration of the production and the evolution from traditional to modern. "Modern" people live in a modern society, think they are superior and look down on traditional society. The incorporation of these traditional societies in the extern zones in the periphery of the worldsystem was associated with a modernisation process. The traditional values, culture and beliefs are, to make them compatible with the hegemonic modernity and world-economy, being converted. Sport was in that process just another expression of euro-centric diffusionism and the modernisation process of European colonialism. The colonial powers believed that they had the ideological mission to diffuse their civilisation through economical, political and military pressure. The purpose was a transformation of the traditional society in a modern and for the core region functional universal world culture. The incorporation of Africa and more particular coastal Africa as a peripheral part of the world-system took place at the end of the 19th century when Britain was dominating the world-economy.

"The primary objective of this sudden imposition of colonial administration on most of Africa, was to establish political control of the territory, which thereby made it possible to establish primacy in its economic transactions", (Wallerstein, 1986: p.16).

The European powers and the political order divided the continent and administration was, sometimes by force, established by the colonial rulers. The incorporation brought the continent new languages, (popular) cultures (sports) and beliefs, which resulted in cultural transformation or domination. The objective of the British colonial policy was to maintain an effective and cheap colonial system, which would rule over the local population. 
The main reason to install a ruling policy was to maximise the production and trade profits but the assimilation of the black Africans was of no interest ${ }^{7}$. The British with their scientific beliefs in social Darwinism and environmental determinism were at that time convinced that muscular Christians only, could rule an empire. The Mid-Victorian and Edwardian public school system created a colonial administrator, a fair play gentleman and an athlete.

"The public schools...claim that it is they who, if they did not make the empire, at least maintained and administered it through their members", (Mandell, 6: p.21).

The spatial diffusion and globalisation of modern sport followed a predictable path and the relocation to the world outside Europe was catalysed by migration, economic and political expansion. The process was associated with colonisation and international trade and the employees of English firms, priests, soldiers and media transplanted these modern sports on the local elite in places with a social, cultural and ideological adaptive atmosphere.

"All colonies had been saturated during the classical colonial era with the ideological message that economic and social progress for the colonial people had to come through the diffusion of "modernisation" from the colonial power", (Blaut, 1993: p.28).

Colonialism was according to Hobson, (1994) a transplantation of certain segments from the homeland to create a corresponding culture in the new territories. The modernised local elite with their western education or the local administration and soldiers were the core of further internal diffusion, but were also the reason for the vanishing of the local folk games. The sports of the British Empire were associated

\footnotetext{
${ }^{7}$ This was one of the differences between the British and France colonial politics. France tried to assimilate the local population. They recruited Africans from other French territories, which were already accustomed to European values and beliefs, to enter in the administration. They were an African expatriate elite in the newly colonised regions. The French policy was to assimilate, as many Africans needed for their purposes.
} 
with status and distinguished the local elite from "the people"; they had an international emanation and a sign of modernity. In a later stadium the sports were adopted, directed through social hierarchical cascade effects, by common people. People who were willing to be a part of a higher social group copied the behaviour of the dominant group and left their traditions. The substitution of the local folk games in Africa, Latin America, Caribbean and great parts of Europe by the English modern sports resulted in the total acceptance of these sports.

\subsection{Modern sport in Sub-Sahara Africa}

"The game of football played in the afternoon, was played for moral benefit as much as recreational relief...to stiffen the backbone of these boys by teaching them manliness, good temper and unselfishness... qualities amongst others which have done so much to make a Briton", (Bale \& Sang, 1994: p.77).

\section{a) Spatial diffusion and British modernity}

As we notice in the introductory quote of the English educationist Sir Frederick Lugard the English public schools created well-trained gentlemen for the imperial administration. These were, in combination with the colonial soldiers and the missionaries, the diffusion channels for the modern sports in the continent. The British believed that they were the chosen imperial race with the gift to rule. Social Darwinism and physical determinism led to a vision of supremacy. According to the 19th century vision, Africa was a backward or underdeveloped part of the world. The result was an autocratic and paternalistic domination with a lack of participation for the black African people and a direct manipulation of the leisure time. "White" sport was a form of popular culture and social control but also a form of social and cultural exclusion.

The spatial dispersion in the continent started at the coastal settlements. The meaning of this internal diffusion was to bring the 
ideals of the English elite to the interior and to stabilise the Empire. Sport or what we call leisure time practices had, like in the preindustrial western society, the aim to reinforce the identity of a community or it was a festivity in the evolution form youth to adulthood. Wrestling, stick fighting, dancing and swimming played an important role and these activities were found in the pre-colonial society in the extern zone of the world-system. The colonial system introduced a new form of ownership, taxation and wage economy and created urban villages. These radical transformations resulted in the alienation of the local black inhabitants. The ethnic groups we know today in Africa are not the primordial institutions of tradition, but they are a recent phenomena based on the region, city, suburb or community that was formed during the period of colonialism.

\section{b) Rugby versus football in Sub Sahara Africa}

Football was introduced in the urban areas and the elite-schools. In the urban centre European settlers used the game to compete against the local African population. Schools taught it to the local black elite and missionaries found it a way to divert the local pupils in the missionary schools. However, the game was originally brought for the white settlers and there were no attempts to create a competition or training structure for the black people. In the beginning the game was, just like any other institution, another tool of segregation and social control. In the French territories there was already a foreign black elite in the administration that was recruited to play football with the settlers, but the local population was not invited for those games. In the early stage football was an instrument of social exclusion and segregation. According to Stuart, (1995) a football club was during the colonial period one of the very few African-run organisations that would be tolerated by the local authorities. Other structures such as ethnical or cultural societies, political parties, trade unions,... were banned or controlled. Like in every totalitarian system sport was/is a way of release and became/becomes an ideal tool for any form of forbidden expression. The football clubs represented an urban area, which was usually an expression of an ethnic community created in the urban areas themselves. The identification and the embodiment of the local 
or regional ethnic groups with a football club were the first indication of the existence and creation of a platform of resistance against the colonial rulers. Football evolved like it did in the rest of the world from a 19th century culture intensive sport to a culture neutral professionalised mass sport that is still the most popular of the continent.

Rugby was introduced and played by the white settlers in the so-called white dominions. They distanced themselves from the local population and evolved into an expression of racial segregation. The white elite adapted Rugby because the sport was practised and diffused through elite schools and universities and was associated with the white race ${ }^{8}$. Football on the other hand was also played at the black elite-schools and was introduced in the industrial urban areas. The South-African and Rhodesian authorities used football as a means of social control. The administration and the mine owners hoped that football would divert the black people from militancy, drunkenness and union membership, (Clayton, 1987: p.117; Archer, 1987; Van Bottenburg, 1994: p.228; Stuart, 1995: p.28-34; Augustin, 1995: p.55; Mclancy, 1996: p.12).

\section{c) Cricket: the game of the masters}

Gutmann, (1994) and Hutchinson, (1996) selected both besides football, cricket in their books about Empire games as typical examples of British sports in the White dominions. British soldiers introduced the game of cricket in South Africa. It was the hegemonic and "racial" sport only played by the white settlers. The sport confirmed and conserved the existing social and political structures and was therefore not a sportnationalistic vehicle for the black Africans. It was and is the expression of the "old" British values, the identity of the "Englishman", the gentleman-player. Cricket is played by the local white elite and considered as a manifestation of "the art of being British". In the international Cricket Council (ICC), the

\footnotetext{
${ }^{8}$ South-Africa is placed third in the worldranking.
} 
organisation that represents and organises the international cricket competitions has, at the moment, 10 "full members"9.

South Africa and Zimbabwe are the only two African members and represent the "white" population in the country involved.

\subsection{Sport and politics in Africa}

"Accordingly, the people understood Uhuru to be complete freedom from all forms of colonial domination, oppression, exploitation and humiliation. It meant total liberation and emancipation from colonial ideological, technical and cultural domination... Culturally, the people aspired to see the end of cultural alienation", (Machyo W'Obanda, 1996: p.37).

\section{a) Sport and national identity in Africa}

In this quote Machyo W'Obanda supposes that the African continent should, in order to create the Pan-Africanism, eliminate the impact of western cultures and re-introduce or re-invent the traditional cultural values, standards and beliefs. The question that can be asked is why African rulers never rejected the western modern sport. On the contrary, they used it to install and maintain their power. The reason for this political behaviour can be located in the colonial history of the continent. In 1884-85 the main European powers at the Congress of Berlin agreed to "stake out their own spheres of influence in Africa... Lines on a map where often drawn with no regard for cultural and linguistic ties, or even with regard to relationships of kinship or lineage", (Corbridge, 1993: p.176).

After the independence these historical and artificial borders, combined with the colonial created ethnicity, led to a form identity crises. What was lacking in these artificially created "nations" was a

\footnotetext{
${ }^{9}$ England, Australia, New Zealand, Sri Lanka, India, Pakistan, Bangladesh, West Indies (collusion of British ex-colonial territories in the Caribbean), South-Africa and Zimbabwe (www.cricket.org/national/icc/members).
} 
form of national identity, which embraces themes dealing with "our homeland", "nation", "ours" and "theirs", as the morality of national duty and honour. Moreover, these themes should be widely diffused and common knowledge. Having a national identity involves being located physically, socially as well emotionally. The traditional identity is based on membership, dependence on a common social group and the cultural identity, which is a fixed object. A part of this traditional identity is a bond with a territorial dimension and this has been passed on from generation to generation. These with ethnical and national ideas imbued identity create a potential for the connection "blood and soil". An ethnical community, a people, only exists when this solidarity is developed when it is based on the personal identification with this culture. The problem in Africa is that the colonial powers that divided the continent never considered the precolonial ethnical composition and the complete fabrication of national histories and customs, the typical western "invented traditions", were rare. The essence of the colonial policy laid in the fact that the power to rule had been abstracted from the local population and placed in the hands of the motherland, with which the local communities had nothing in common. The colonists did not create a new national identity and when they became independent there was no collective consciousness on which the local rulers could depend. Fieldhouse notices that "Until then the imperial powers could deal with localities rather than countries: it could rule by division without having to divide", (Fieldhouse, 1999: p.72). The result was that after the independence the newly decolonised nations had their identities, which were difficult to use. A form of re-invention or resurrection of the local pre-colonial culture could be dangerous and could lead to civil wars. Taylor \& Flint (2000: p.117) noticed that the decolonisation in Latin America in the first quart of the 19th century was more realigned in the world-economy under British formal liberal leadership. The decolonisation of Africa after World War II encompasses socialist-inspired revolutions that have been more anti-systemic in nature. Nationalism in Africa was a combination of the creation of an imagined community in combination with a resistance against the core of the world-system. 
Nielsson, (1985) identifies 57 non-nation-states ${ }^{10}, 42$ are located in Africa. Multinational states (14 of 19) and bi-national states ( 9 of 21 ), reflections of the colonial arbitrary division of the continent, are also located in Africa. The lack of unifying myths and identities in all its forms resulted in the quest for a new useful nation-state building imagined community spirit. The solution developed by some of the African nations was the use of a western, colonial, popular culture "sport" to create a form of nationalism. The significance of sport lays in the fact that place and territory and more specific the symbolic locationpride or "topophily" are central topics. Sport participates in an explicit manner in the territorialisation process and has the capacity to be a powerful catalyst for the creation of a national identity. Sport is in the whole world an instrument of nationalism but in Africa was is most of the time used as a nation creating factor, in the rest of the world was it used beside other invented traditions or the creation of cultural homogeneity in history and language. The creation of the nations in Europe or the independence in Latin America occurred in a period where "modern sport" wasn't invented. Sport is in these zones used in a latter phase as a confirmation of a political system or nation. Sport was, in the post-colonial nations in Sub-Sahara Africa, an inherent instrument for national unification and integration and even supplied a safety valve for emotional energy. In the international comparison of nations are, besides the hierarchical classification of the $\mathrm{BNP} /$ capita or $\mathrm{BRP} /$ capita, the achievements of sportathletes or sportteams an indicator for success and prestige, and the mass supports their national representatives. Sport defines in an explicit way the imaginary political community and provides a unique effective medium to calculate in national feelings. The sportteams represent the local state and the international games became an expression of patriotism. Arnaud defined sportnationalism as:

\footnotetext{
${ }^{10}$ Non-nation-states lack a single ethnic group that has $60 \%$ of the state's population. He divides them in three types. An intermediate non-nation state (40-60\% of a single ethnic group), bi-nations-states ( 2 ethnic groups provide $65 \%$ ) and multinational states with a high degree of ethnic fragmentation.
} 
"the exarcebation of a chauvinism, of a xenophobia or, in a euphemistic way, of a "marked preference" for one's country. It is vying for its "honour", its reputation, its "identity"", (Arnaud, 1998: p.7).

The political elite can stimulate the sportachievements so that the nation is successful in the international competition. This kind of policy has a symbolic function because it is the only opportunity for the "poor" countries to beat the "rich" or transplanted on Africa by the ex-colonial powers. Sport is in this sense a way to classify themselves and others hierarchically.

In the beginning of the seventies the Nigerian minister of sport declared that:

"Sporting achievements not only help to integrate the people but are also a measure of the nation's greatness", (Jarvie, 1990: p.69-70).

The African leaders used sport as a potent symbol for the creation of the nation-state and the struggle for international recognition. Sport and most of all the culture neutral football and not the culture intensive rugby or cricket was used as an easy and simple way to develop national loyalty and sentiment. The sportidols honoured on the international competitions the national flag and they became the unofficial, a-political ambassadors and symbols of national unity. Sport created a positive image of the nation and diverted the attention from the poverty and destabilisation. The meaning of sport for national identity, the unity of the nation, international prestige and the Pan-African cohesion is interwoven in the history of Africa's struggle for independence. The strong relation between sport and nationalism makes that the level of competence of the African nations or ethnic group is associated with their performance on the field. The level and competence of the African nations is related to the performances of the national football team and are an indicator of prosperity and an expression of nationalism and Pan-Africanism. This positive relational connection between politics and football can be transformed into a negative factor. The failure of a club can be interpreted and associated 
with political failures, (Baker, 1987; Jarvie, 1990; Monnington, 1990; Corbridge, 1993: p.176-177; Wagg, 1995: p.34-37; Nkwi \& Vidacs, 1997: p.123-139; Sugden e.a., 1998: p.27; Hayatou, 1998).

\section{b) Football and African politics: some examples}

"Soccer, popular among both the labouring classes and the African elite, became an ideal tool with which to win mass support from the majority of the population. African political leaders were not slow to exploit soccer in this way. Even today politicians in Africa ensure that they are closely associated with the most popular team in the country", (Stuart, 1995: p.34).

The first African leader who used football for political purposes was Kwame Nkrumah, the president of the first independent country of black Africa, Ghana. In the early sixties, he promoted, as the leader of the locomotive of Africa, the creation of a new, strong and modern continent that had to rise against colonial oppression and exploitation. He dreamed of a new economic and political superpower, the United States of Africa. Sport could, according to him, play an important role in the creation of a national unity and the nations. Football obtained a function of fraternity and national peacekeeper. The African Cup of Nations, better known as the Africa cup, created in 1957, as a tournament between the African national footballteam, is the symbol of the popularity of football in the continent. It was the first potential opportunity of an arising nationalism. The victory of Ghana's national team, the "Black Stars", in 1963 and 1965 were not only an expression of the sportive superiority of Ghana in the continent, but was also interpreted as an expression of the supremacy of Nkwane Khrumah's economic and political philosophy. After the military "coup d'état", football one of the priorities of Nkrumak, was neglected and this resulted in the poor performances of the national team until 1978. Idi Amin, the leader of Uganda between 1971 and 1979, used football to obtain international prestige. The national team had its best period under his government. Parallel to the situation in Ghana football was neglected after the putsch. The best example of unity around the flag 
was Cameroon. The British and the French took this territory from the Germans in 1916. After the independence in 1960 Ahidjo took, with the support of the French, power and ruled the nation during 25 years with an iron hand. Sport and culture were the only places where some autonomy existed. Football developed according to regional and ethnic lines but in the period of international ascension the control of the central government increased. They organised a fundraising operation "Coup de Coeur" after the "lions" reached the quarter finals at the World Championship in Italy 1990, to finance the preparation of the national team for the World Championship 1994. The strong association between sport and government can transform it in a threat. Biya, the president of Cameroon, cancelled the elections in 1994. The reason was the poor performances of the national team at the world championship in the US in 1994 . He was afraid that the population would blame him personally for this.

In South Africa the connection between football and politics is even stronger. Football is an overwhelmingly black sport, unlike cricket and rugby, which remain overwhelmingly white, despite the collapse of apartheid. The national team was because of the "apartheid" expelled for international competitions. During that regime football was initially organised in 4 racial associations. In 1978, long before the end of apartheid, they decided to create one association with mixed teams. On the day of his election, Nelson Mandela, the president after the apartheid, attended a football game of the national team "Bafana Bafana" in Johannesburg. In 1996 South Africa organised the Africa Cup. To conquer this cup was, after all those years of exile, very important. The coach of the national team said just before the tournament that a victory for his country would be more than winning a sport contest. Football, he said, is more than a game. It was during the terrible period of the apartheid the only possibility for blacks to prove they were better than whites. It was at that time a racial thing; you could see it in the stadiums. The blacks expressively demonstrated their superiority. Therefore conquering the Africa Cup would have been a success of black South Africa. The wish to win is not a sportive demand but a social duty. South Africa won against all expectations and during the final Mandela sat besides vice-president De Klerk and Inkatha, leader Buthelezi, (Stuart, 1995: p.37-39; Broere 
\& Van Der Drift, 1997: p.40-46: p.66-67; Nkwi \& Vidacs, 1997: p.124; Hayatou, 1998: p.66-70; Daniels e.a., 2001: p.160).

The FIFA, the "Féderation Internationale de Football Associations" made up a ranking of the 10 best African footballnations of the 20th century. They used their performances in the World Championship and the African Cup. The result of this ranking system can be partially explained by the sport policy used. In this top 10 we find 7 black African nations. Cameroon is 1st, Nigeria 3rd, South Africa 4th ${ }^{11}$, Senegal 7th, Ivory Coast 8th, Ghana 9th and Angola $10^{\text {th }}$, (www.fifa.com; 15/03/2002).

\section{c) Globalisation and football in Africa}

"It is not the competence of the European representatives in the FIFA executive which is at stake but rather the future of Europe in world football... at the FIFA Congress in Mexico, political questions were given precedence over questions of sport and a clearly anti-European attitude had been exhibited there", (Quote of Louis Wouters the Belgian representative, (Sugden e.a., 1998: p.14)).

The international regional organisation, which represents the African nations, is the CAF, the "Conféderation Africaine de Football"12. The global development of world football finds its roots in the three tiers structure of the world-system. Jules Rimet, the French chairman in the period 1921-1954, considered the FIFA as a family with a paternalistic and neo-colonial (read modernisation), vision on world development. Drewry and Rous, the chairmen in the period 19561970, also adopted this Eurocentric and neo-imperialistic policy.

11 South Africa was excluded between 1957 and 1992. Otherwise they probably should been placed a few ranks higher.

12 The CAF was founded in 1957 by the independent nations Egypt, Sudan, South Africa and Ethiopia. South Africa was immediately banned because they recruited only white players for their national team. South Africa returned in 1992 after the fall of the apartheid. Nowadays the organisation has 52 members and is thereby the largest regional confederation of the FIFA. 
The globalisation of football and the decolonisation after World War II resulted in a significant growth of Third World members and a theoretical diminishing of the European impact ${ }^{13}$. These Third World nations wanted to use the FIFA as a political platform for their expressions of independence and national identity. The coup of the Third World came in 1974 when the Brazilian Havelange was elected as chairman. The policy of the former and beaten chairman Rous was the main reason for this victory. Havelange represented the Third World and a political blunder ${ }^{14}$ of Rous made that the communist countries also voted for Havelange. Africa voted "as one" for Havelange. Another reason was that Rous refused to eliminate South Africa in the international competitions. These blunders combined with the promises Havelange ${ }^{15}$ made to Asian and African countries made him win the election, (Tomlinson, 1991: p.95; Wagg, 1995: p.12; Duke \& Crolley, 1996: p.2-4; Sugden e.a., 1998: p.16).

The political assumption of power of the periphery and semiperiphery resulted in a declining number of European FIFA officials and an increasing pressure on their policy. These changes in the working of the FIFA have not yet led to an assignment of the organisation of the world championship to the African continent.

\footnotetext{
${ }^{13}$ The FIFA principle "one nation, one vote" implied the creation of a power centre for the Third World. The European associations anticipated on this global evolution. They installed a $75 \%$ majority requirement necessary for regulation changes. The UEFA had with its 51 members (203 ranked members (www.fifa.com)) a blocking minority.

${ }^{14}$ Rous refused the membership op the People's Republic of China. Instead he kept Taiwan as a member of the FIFA. A second and even greater blunder was the demand that the USSR had to play its match against Chili in the national stadium where Pinochet had tortured and executed leftwing political dissidents. The USSR refused to play and lost the game.

${ }^{15}$ The promises he made were:

- increasing the number of participating nations to the World Championship from 16 to 24

- increasing the number of participants from the Third World

- organising international youth championships in the developing countries

- giving financial aid for stadiums and football education

- creating international competitions in Africa and Asia
} 
Argentina, (1978), Mexico, (1970, 1986), and Japan/South-Korea (2002), nations located in the semi-periphery and core of the worldsystem, have already been allowed to organise the World Championship. However, the latest attribution for the World Championship 2006 clearly shows us the impact of Europe. South Africa was in the running for the final voting. The result of the election was a 12-11 victory for Germany and an abstention of the representative of New Zealand ${ }^{16}$. The South-African president Mbeki accused the FIFA of global "apartheid". He said that the European countries were still determined to marginalise Africa.

A consequence of globalisation in an existing world-system is the resource transfer from periphery to core. Sports labour migration can be linked to cultural en economic globalisation. The globalisation of social network and trade connections in the world-system results in an increasing interdependency and labour migration from periphery to the core. With a few exceptions, football in Africa is not professionalized and a migration to Europe has traditionally been the only way of becoming a professional player. Africa has in this context become the main donor of Europe for football players. In terms of Wallerstein's world system has the core area, given their dominance over the world-economy, has the power to exploit and impoverish the periphery by organising world trade to favour their own interests. According to Darby (2001: p.235) is the flow of sports talent from Africa to Europe is correlated with the ideas of hierarchical dependency and exploitation within the world-system. The core nations utilise their position to exploit underdeveloped football regions in the post-colonial era. The chairman of the CAF, Hayatou articulated his concern about the impact of player migration on African football in the statement:

16 UEFA (Europe) and AFC (Asia) voted for Germany and CAF (Africa), CONMEBOL (South-America) and CONCACAF (Middle and North America) voted for South-Africa, (Dejonghe, 2001b: p.170). 
"After the flight of brains, Africa is confronted with the muscle exodus. The rich countries import the raw material - talent - and they often send to the continent their less valuable technicians. The inequality of the exchange terms is indisputable. It creates a situation of dependence... The elite of African football is out of the continent... Prestigious clubs are regularly deprived of their best elements and even the juniors cannot escape the voracity of the recruiting agents", (Hayatou, 1998: p.37).

African football migration can be seen as an extension of the economic and political relationship between the core and the periphery. The ability of the African clubs is restricted. They cannot pay the wages that are given and promised in the rich core countries. The globalisation of sport resulted in a further inequality and the talented players migrated to the rich core.

The flow of African players to the European leagues expanded since the 80s. Darby (2001: p.220-222) noticed acceleration in the transcontinental migration of African football players. In his research about the African National Cup in 2000 he noticed that 178 of the 352 players played in the competitions of other continents. The competitions of France, Belgium, Portugal, Germany and England had the largest number of African players. He associated this with their significant colonial presence in Africa. The role of France in this context can be linked with their colonial assimilation policy. The local population had to be converted into a citizen of the motherland. This form of gallicisation resulted in a high percentage of naturalisation. The Africa Cup 2002 played by 16 national teams in Mali consolidated this labour migration from the periphery to the centre. From the 329 players that were registrated by club of origin ${ }^{17} 186$ $(56,5 \%)$ played in Europe and 8 in another continent. (www.dailysoccer.com,15/03/02). We still notice the dominance of France, the increasing impact of the strong football nations Germany, Italy and England and the place of Belgium as a transition country.

\footnotetext{
${ }^{17}$ Liberia was the only country without a list of origin (www.dailysoccer.com,15/03/02).
} 


\begin{tabular}{|l|c|l|c|}
\hline \multicolumn{1}{|c|}{ Continent } & Players & Country in Europe & Players \\
\hline Africa & 135 & France & 62 \\
Asia & 7 & Germany & 19 \\
Central America & 1 & Belgium & 18 \\
& & Italy & 15 \\
& & England & 15 \\
& & The Netherlands & 11 \\
& & Turkey & 10 \\
& & Spain & 9 \\
& & Switzerland & 8 \\
& & Greece & 6 \\
& & Others & 13 \\
\hline
\end{tabular}

Table 2: The "working place" of the players on the Africa Cup

In Belgium we notice an increasing relative and absolute number of foreign and African players. The percentage of foreign players in our competition evolved from about $25 \%$ in 1970 , over $37,1 \%$ in 1990 , to $57,7 \%$ in 2001. In absolute numbers this is an increase from 64 in 1970 to 244 in 2001. The migration accelerated after the Bosman case in 1995 that made it easier to migrate to and within Europe. Belgium has compared to the competitions in England, Germany and The Netherlands - low minimal wages. This factor combined with a good infrastructure and further training makes Belgium the perfect transition country for potential topplayers ${ }^{18}$. The Belgian football competition becomes a location where clubs from the topcountries place their potential talent. The result is an increasing number of foreign players. Some clubs are specialising in buying African players

\footnotetext{
${ }^{18}$ In Belgium the minimal wage of a professional football player is $€ 35.000$. In the Netherlands, $€ 225.000$ (average wage of the professional players in the first division) and in England there is an additional quality classification. The non-EU player has to play several times for their national team. The result is that Dutch and English clubs to "dump" their "potential" non-EU players uses Belgian clubs.
} 
in the hope to sell some of them with profit ${ }^{19}$. In the period up to 1985 less than 10 African players played in our first division. That number increased to over 30 in 1991, to 60 in 2002.

\section{CONCLUSION}

Sub-Sahara Africa is, analogue to Wallerstein's world system, a peripheral region in the world sport system. The region accepted, with the exception of the "white settlers" in Zimbabwe, Namibia and South Africa, in a passive way the British hegemonic popular culture "modern sport" without any form of cultural resistance. The modern sports that are practised are originally British and it is the culturally neutral sport, football, that has the greatest popularity. Rugby and cricket, two culturally intensive sports are/were an expression of racial segregation and are connected with the traditional "white settlers" values and beliefs. One of the main problems after the decolonisation was, because of the arbitrarily laid borders, the finding of a national identity. For this purpose the African leaders used a typical, via cultural imperialism introduced item "modern sport" and more specific the location sport football, as a newly invented tradition. One of the central topics in football is "topophily" the connection with "blood and soil" and it creates a pride in the territory. This sportnationalism is the reason why the African leaders did not reject football, although it was associated with the colonial powers. They transformed it for their purpose and even made a connection between success in sport and economical and political successes. Sport also made it possible to beat the ex-masters, something they were not able to by economical means.

The recent globalisation processes reinforce the dependency of the continent and results in an increasing "footdrain", labour migration, of African athletes. The continent has become more and more a source of "cheap" athletes for the core and semi-peripheral sportnations. The

\footnotetext{
${ }^{19}$ Clubs like Sp Lokeren SNW and SK Beveren are working together with clubs in Africa.
} 
athletes are handled and used as a form of "cash crop" that can be transferred from one country to another. The result is the confirmation of the economical and sportive peripheral situation of the continent.

\section{BIBLIOGRAFIE}

APPARADUI, A., (1990), Disjuncture and difference in the global culture economy, Theory, culture and society, 7, p. 295-310.

ARCHER, R., (1987), Politics and sport in South Africa's townships, in: Baker, W. \& Mangan, J., "Sport in Africa", Africa Pub, Comp, New York, p. 229-248.

ARNAUD, P., (1998), Sport - a means of national representation, in: Arnaud, P. \& Riordan, J., (ed.), "Sport and international politics", E\&Fn Spon, London, p. 14-30.

ARUNDEL, J. \& ROCHE, M., (1998), Media sport and local identity: British rugby league and sky tv, in: Roche, M.,(ed.) "Sport, popular culture and identity", Meyer \& Meyer Verlag, Aachen, p. 57-91.

AUGUSTIN, J-P., (1995), Sport, géographie et aménagement, Nathan Un Press, Paris.

BAKER, W., (1987), Political games: the meaning of international sport for independent Africa, in: Baker, W. \& Mangan, J., "Sport in Africa", Africa Pub, Comp, New York, p. 272-292.

BALE, J., (1994), Landscape and modern sport, Leicester Un Press, Leicester.

BALE, J. \& SANG, J., (1994), Out of Africa: The "development" of Kenyan athletics, talent, migration and the global sport system, in: Bale, J. \& Maquire, J. (ed), "The global sports arena", Frank Cass, London, p. 206-225.

BECK, U., (2000), What is globalization?, Polity Press, Cambridge.

BLAUT, J., (1993), The colonisers of the world: geographical diffusion and eurocentric history, The Guilford Press, New York.

BROERE, M. \& VAN DER DRIFT, R., (1997), Afrika voetbalt!, NCOS, Brussel.

CLAYTON, A., (1987), Sport and African soldiers: the military diffusion of western sport throughout Sub-Saharan Africa, in: Baker, W. \& Mangan, J., Africa Pub Comp, p.114-137. 
CORBRIDGE, S., (1993), Colonialism, post-colonialism and the political geography of the Third World, in "Political geography in the 20th century", Taylor, P. (ed), Belhaven, New York, p.173-205.

CRANG, M., (1998), Cultural geography, Routledge, New York.

DANIELS, P., (2001), Human geography, issues for the 21 st century, Prentice Hall, Essex.

DARBY, P., (2001), The new scramble for Africa: The African football labour migration to Europe, Mangan, J.(ed), Europe, sport world: shaping global societies, Frank Cass, London, p.217-244.

DEJONGHE, T., (2001a), De noodzaak aan exogeen opgelegde economischgeografische principes bij het professionaliseren van het door endogene factoren ontstane wereldsportstelsel; gevalstudie: het lokalisatievraagstuk van het topvoetbal in België, doctoraatsverhandeling Universiteit Gent, eigen uitgifte, Gent.

DEJONGHE, T., (2001b), Sport in the wereld: ontstaan, evolutie en verspreiding, Academia Press, Gent.

DUKE, V. \& CROLLEY, L., (1996), Football, nationality and the state, Longman, London.

DUNNING, E., (1999), Sport matters, sociological studies of sport, violence and civilisation, Routledge, London.

ELIAS, N. \& DUNNING, E., (1986), Quest for excitement: sport and leisure in the civilising process, Blackwell Pub, Cambridge.

FIELDHOUSE, D., (1999), The West and the Third World, Blackwell Pub, Oxford.

FRIEDMAN, J., (1994), Cultural identity and global process, Sage, London.

GELLNER, E, .(1994), Naties en nationalisme, Wereldbibliotheek NV, Amsterdam.

GIDDENS, A., (1990), The consequences of modernity, Polity Press, Cambridge.

GUTTMANN, A., (1994), Games and empires: modern sports and cultural imperialism, Columbia Un Press, New York.

HAYATOU, I., (1998), L'importance du football dans les pays Africain, in: "Géopolitique du football", Boniface, P. (ed), Editions complexe, Paris, p. 36-42.

HOBSON, D., (1994), Geography and national identity, Blackwell Pub, Oxford. 
HOULIHAN, B., (1994), Homogenization, Americanization and creolization of sport: Varieties of globalization, Sociology of Sport Journal, 11, p. 356-375.

HUTCHINSON, R., (1996), Empire games: The British invention of 20th-century sport, Mainstream pub, Edinburgh.

JARVIE, G., (1990), Sport, nationalism and cultural identity, in: Addison, L. (ed), "The changing politics of sport", Manchester Un press, Manchester, p. 55-83.

MACHYO W'OBANDA, C., (1996), Conditions of Africa at home, in: "Pan Africanism, politics, economy and social change in the 21 th century", Abdul-Raheem, T. (ed), Pluto Press, London, p. 33-66.

MANDELL, R., (1986), The games ethic and imperialism, Viking Press, New York.

MANGAN, J., (1986), The games ethic and imperialism: aspects on diffusion of an ideal, Viking Press, New York.

MANGAN, J., (2001), Prologue: imperialism, sport, globalization, in: Mangan, J. (ed), Sport, world society: shaping global societies, Frank Cass, London, p. 1-4.

MAQUIRE, J., (1994), Sport, identity, politics and globalization: Diminishing contrasts and increasing varieties, Sociology of Sport Journal, 11, 4, p. 398-427.

MAQUIRE, J., (1999), Global sport: identities-societies-civilizations, Polity Press, Cambridge.

MARSHALL, D., (1996), National development and the globalization discourse, Third World Quarterly, 17, p. 875-901.

MAZRUI, A., (1976), A world federation of cultures: an African perspective, The Free Press, New York.

Mc CLANCY, J., (1996), Sport, identity and ethnicity, Berg, Oxford.

MITCHEL, D., (2000), Cultural geography: a critical introduction, Blackwell, Malden.

MONNINGTON, T., (1990), Politicians and sport: user and abuser, in: Allison L. (ed), "The changing politics of sport", Manchester Un Press, Manchester, p. 125-150.

NEDERVEEN PIETERSE, N., (1995), Globalization and hybridization, in: Featherstone, M. \& Robertson, R. (ed), "Global modernities" Sage, London, p. 44-58.

NIELSSON, G., (1985), States and "nation groups": a global taxonomy, in: Edward, A. e.a. (ed), "New nationalism in the developed west", Allen \& Unwin, Boston, p. 2956. 
NKWI, P. \& VIDACS, B., (1997), Football: politics and power in Cameroon, in: Armstrong, G. \& Guilianotti, R. (ed), "Entering the field", Berg, Oxford, p. 123-140.

RENSON, R., (1997), The reinvention of tradition in sports and games, Journal of Comparative Physical Education and Sports, 19, vol. 2, p. 46-52.

ROBERTSON, R., (1992), Globalization: social theory and global culture, Sage, London.

SCHILLER, H., (1976), Communications and cultural domination, Sharpe, New York.

STUART, O., (1995), The lions stir, football in African society, in: "Giving the game away", Wagg, S. (ed), Leicester Un Press, London, p. 24-51.

SUGDEN, J. \& TOMLINSON, A., (1998), Sport, politics and identities: Football cultures in comparative perspective, in: Roche, M. (ed), "Sport, popular culture and identity", Meyer \& Meyer Verlag, Aachen, p. 169-192.

TAYLOR, P., (1996), The way the modern world works, world hegemony to world impasse, Wiley, Chichester.

TAYLOR, P., (1999), Modernities, a geohistorical interpretation, Routledge, London.

TAYLOR, P. \& FLINT, C., (2001), Political geography, world-economy, nation-state and locality, Prentice Hall, Harlow.

TOMLINSON, J., (1991), Cultural imperialism, Pinter Publishers, London.

VAN BOTTENBURG, M., (1994), Verborgen competitie, Uitgeverij Bakker, Amsterdam.

WAGG, S., (1995), Giving the game away: football, politics and culture in five continents, Leicester Un press, London.

WAGNER, E., (1984), Sport in Asia and Africa: a comparative handbook, Greenwood Press, New York.

WAGNER, E., (1990), Sport in African and Asia: Americanization or mundialization?, Sociology of Sport Journal, 7, 4, p. 399-402.

WALLERSTEIN, I., (1974), The modern world-system, I The capitalist agriculture and the origins of the European world-economy in the 16th century, Academic Press, New York. 
WALLERSTEIN, I., (1986), Africa and the modern world, Africa World Press Inc, Trenton.

WATERS, M., (1995), Globalization, Routledge, London.

www.cafonline.com

www.cricket.org

www.fifa.com

www.dailysoccer.com 